\title{
A bloom of cyanobacteria (Cylindrospermopsis raciborskii) in UHE Carlos Botelho (Lobo/Broa) reservoir: a consequence of global change?
}

\author{
Tundisi, JG. ${ }^{a, b *}$, Matsumura-Tundisi, T. ${ }^{a}$, Tundisi, JEM. ${ }^{a}$, Blanco, FP. ${ }^{a}$, Abe, DS. ${ }^{a}$, \\ Contri Campanelli, L. ${ }^{a}$, Sidagis Galli, G. ${ }^{a}$, Silva, VT. ${ }^{a}$ and Lima, CPP. ${ }^{a}$ \\ anstituto Internacional de Ecologia, Rua Bento Carlos, 750, CEP 13560-660, São Carlos, SP, Brazil

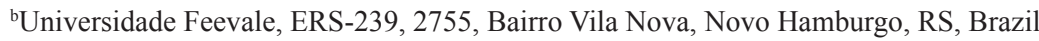 \\ *e-mail:tundisi@iie.com.br
}

Recieved: November 7, 2014 - Accepted: December 11, 2014 - Distributed: May 31, 2015

The UHE Carlos Botelho (Lobo/Broa reservoir) was selected in 1971 for a program of ecological research, and in the last 44 years continuous sampling and studies, characterized very well this artificial ecosystem and its watershed (Tundisi and Matsumura Tundisi, 2013). The mechanisms of functioning of the reservoir were well known and the maintenance of good water quality (low conductivity - average $\left(10-20 \mathrm{uSxcm}^{-1}\right.$; periodic turbulence with re-oxygenation of the whole water column, and high saturation of oxygen (80-100\%); low retention time ( $<20$ days) and a extensive macrophyte grow in the headwaters that prevent high nutrient load. This is the picture for the last 44 years. The phytoplankton composition was consistent with the oligomesotrophic characteristic of the reservoir: predominance of diatoms and chlorophyceae with a maximum of $10 \mu \mathrm{g} / 1$ chlorophyll. However in the winter of (july) 2014 the following changes were observed: a heavy bloom of cyanobacteria occurred for the first time in the reservoir. This cyanobacteria Cylindrospermopsis raciborskii, is a invasive species. Very high chlorophyll levels (up to $100 \mu \mathrm{g} / \mathrm{l}$ ) were measured and high concentration and input of phosphorus was also detected (Tundisi and Matsumura-Tundisi, 2014).

The explanation for this sudden appearance of blooms, can be attributed to the following factors: increase of up to $2{ }^{\circ} \mathrm{C}$ above the average water temperature during the winter; lower rainfall during summer $(30 \%$ less of the yearly average of $1.500 \mathrm{~mm}$ ). Increase in the retention time (from $<20$ days up to 60 days) in order to maintain volumes for hydroelectricity production.

This cyanobacteria bloom can be attributed to changes in the regional climate and the hydrological regime, with consequences for the dam operation.

As described by Paerl and Huisman (2008), global warming affects patterns of precipitation and drought. The changes in the hydrological cycle enhanced cyanobacterial dominance. Heavy rains after extensive drought periods, increase nutrient input promoting phytoplankton growth. During periods of drought, residence time, increase, thus promoting blooms.
As a further consequence of this process, extensive periods of drought prevent silica discharge into the reservoir reducing diatom growth; the Lobo/Broa reservoir had a predominance of Aulacoseira italica during many years due to silica concentrations of up to $5 \mathrm{mg} / 1$. This effect of silica reduction was described by Schindler (2006) in his review of eutrophication.

As a result, today, Lobo/Broa reservoir is eutrophic. To our understanding this is a clear evidence of an effect of global changes at a local and regional freshwater ecosystem. Impacts of the cyanobacteria blooms were immediate mainly on recreation, sport fisheries , aquatic sport activities due to the danger of toxicity. Also fish mortality was detected during periods of intense blooms. Its is known from several sources and scientific research that cyanobacteria produces toxins that are harmful to human and animal health. (Carmichael 1992; Azevedo et al., 1994). Analysis of potential production of cyanotoxins during the blooms were performed at the Institute of Biophysics of Federal University of Rio de Janeiro. It was demonstrated that saxitoxins and mycrosystin were present though not in high concentrations. But the potential for the production of harmful cyanotoxins was present and the production of higher concentrations of the toxins is a possible consequence of the blooms in the future.

Effects on the overall economy of the region and on the ecosystem services, are being quantified (Periotto and Tundisi, 2013).

\section{Acknowledgements}

The authors express their thanks to the finantial support of FAPESP (Processes number 51502-3/2012) and CNPq (Processes number 403820/2012-0). This is part of the Long Term Ecological Research Program of CNPq and FAPESP-PELD, and the support of Prof.Dr. Sandra Feliciano de Azevedo from the Institute of Biophysics UFRJ in the identification of the cyanobacteria and toxicity of the blooms. 


\section{References}

AZEVEDO, SMFO., EVANS, WR., CARMICHAEL, WW. and NAMIKOSHI, M., 1994. First report of microcystins from a Brazilian isolate of the cyanobacterium Microcystis aeruginosa. Journal of Applied Phycology, vol. 6, p. 261-265.

CARMICHAEL, WW., 1992. Cyanobacteria secondary metabolites: the cyanotoxins. Journal of Applied Bacteriology, v. 72, p. 445-459.

PAERL, HW. and HUISMAN, J., 2008. Climate. Blooms like it hot. Science, vol. 320, no. 5872, p. 57-58. http://dx.doi.org/10.1126/ science.1155398. PMid:18388279
PERIOTTO, NA. and TUNDISI, JG., 2013. Ecosystem Services of UHE Carlos Botelho (Lobo/Broa): a new approach for management and planning of dams multiple-uses. Brazilian Journal of Biology = Revista Brasileira de Biologia, vol. 73, no. 3, p. 471-482. http:// dx.doi.org/10.1590/S1519-69842013000300003. PMid:24212686

SCHINDLER, D., 2006. Recent advances in the understanding and management of eutrophication. Limnology and Oceanography, vol. 51, no. 1 part2, p. 356-363. http://dx.doi.org/10.4319/ lo.2006.51.1_part_2.0356.

TUNDISI, JE. and MATSUMURA-TUNDISI, T., 2013. The ecology of UHE Carlos Botelho (Lobo/Broa reservoir) and its watershed, São Paulo, Brazil. Freshwater Biology, vol. 6, p. 75-91. 